\title{
Clinical Stage IV Esophageal Squamous Cell Carcinoma AJCC v8
}

National Cancer Institute

\section{Source}

National Cancer Institute. Clinical Stage IV Esophageal Squamous Cell Carcinoma A/CC v8. NCI Thesaurus. Code C133451.

Stage IV includes: IVA: (T4, N0-2, M0); (Any T, N3, M0); IVB: (Any T, Any N, M1). T4:

Tumor invades adjacent structures. N0: No regional lymph node metastasis. N1: Tumor with metastasis in one or two regional lymph nodes. N2: Tumor with metastasis in three to six regional lymph nodes. N3: T umor with metastasis in seven or more regional lymph nodes. M0: No distant metastasis. M1: Distant metastasis. (AJCC 8th ed.) 